Jurnal Pendidikan Matematika : Judika Education

Volume 1, Nomor 2, Juli-Desember 2018

e-ISSN : 2614-6088

p-ISSN : 2620-732X

DOI: https://doi.org/10.31539/judika.v1i2.381

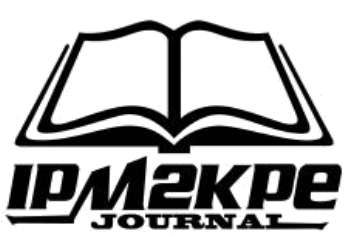

\title{
KEMAMPUAN BERPIKIR KREATIF DAN KEMANDIRIAN BELAJAR MATEMATIKA SISWA MELALUI MODEL PROBLEM BASED LEARNING
}

\author{
Rika Silviani \\ STKIP Bumi Persada Lhokseumawe \\ rikasilviani@gmail.com
}

\begin{abstract}
ABSTRAK
Penelitian ini bertujuan untuk mendeskripsikan kemampuan berpikir kreatif dan kemandirian belajar siswa selama proses pembelajaran model PBL dan mengetahui peningkatan kemampuan berpikir kreatif siswa setelah menggunakan model PBL siswa kelas VIII SMP Negeri 6 Banda Aceh. Penelitian ini menggunakan metode penelitian campuran (mixed methods) dengan strategi embedded konkuren. Sampel dipilih secara random sampling yaitu siswa kelas VIII-3 yang berjumlah 28 orang dari seluruh siswa kelas VIII. Instrumen pada penelitian ini berupa tes uraian harian,observasi dan angket. Instrumen ini digunakan untuk memperoleh data peningkatan kemampuan berpikir kreatif siswa setelah menggunakan model PBL yaitu berupa tes awal (pretes) dan tes akhir (postes), serta instrumen yang digunakan untuk mendeskripsikan kemandirian belajar siswa selama proses pembelajaran model PBL. Analisis data pada hasil tes uraian harian dan observasi menggunakan rubrik penilaian kemampuan berpikir kreatif dengan metode deskriptif kualitatif. Hasil pretes-postes dianalisis dengan uji statistik, dan hasil angket kemandirian belajar dianalisis menggunakan skala Likert dan persentase. Hasil penelitian menunjukkan bahwa siswa kreatif dalam menyelesaikan masalah yang berkaitan dengan perbandingan selama proses pembelajaran model PBL. Simpulan, terdapat peningkatan kemampuan berpikir kreatif siswa setelah menggunakan pembelajaran model PBL. Hasil penelitian juga menunjukkan siswa memiliki kemandirian belajar selama proses pembelajaran model PBL.
\end{abstract}

Kata Kunci: Kemampuan Berpikir Kreatif, Kemandirian Belajar, Model Problem Based Learning (PBL).

\begin{abstract}
This study aims to describe the ability of creative thinking and independent learning of students during the learning process PBL models and find out the improvement of students' creative thinking skills after using PBL models of class VIII students of SMP Negeri 6 Banda Aceh. This research uses mixed methods (mixed methods) with a concurrent embedded strategy. The sample was chosen by random sampling, namely students of class VIII-3, amounting to 28 people from all students of class VIII. The instrument in this study was a daily description test, observation and questionnaire. This instrument is used to obtain data to increase students' creative thinking abilities after using the PBL model in the form of a pretest and a post-test, as well as an instrument used to describe the independence of
\end{abstract}


student learning during the PBL model learning process. Data analysis on the results of the daily description test and observation using the rubric of the assessment of the ability to think creatively with qualitative descriptive methods. The results of the pretest-posttest were analyzed by statistical tests, and the results of the learning independence questionnaire were analyzed using a Likert scale and percentage. The results showed that students were creative in solving problems related to comparisons during the PBL model learning process. Conclusion, there is an increase in students' creative thinking skills after using PBL model learning. The results also showed students had independence of learning during the PBL model learning process.

Keywords: Creative Thinking Ability, Learning Independence, Problem Based Learning (PBL) Model.

\section{PENDAHULUAN}

Peran pendidikan merupakan kebutuhan yang sangat bermanfaat dalam kehidupan manusia. Manusia akan tumbuh dan berkembang serta dapat menanggulangi masalahmasalah yang dihadapi dengan berpikir secara kreatif dan mandiri melalui pendidikan. Pendidikan dapat pula mengembangkan pengetahuan serta meningkatkan mutu kehidupan. Oleh karena itu, pendidikan sangat diperlukan dalam upaya meningkatkan kualitas potensi manusia.

Salah satu upaya meningkatkan potensi manusia adalah melalui pembelajaran matematika. Matematika merupakan suatu konsep abstrak yang diberikan dalam bentuk simbol yang tersusun secara hirarkis dan penalarannya deduktif, sehingga pembelajaran matematika sering dianggap sebagai kegiatan mental yang tinggi (Mulyono, 2003). Matematika mempunyai tahapan dan aturan yang jelas, sehingga dalam mempelajarinya tidak hanya dengan menghafal dan membaca, tetapi juga memerlukan kemampuan berpikir.
Matematika dapat membentuk karakter berpikir siswa menjadi manusia yang berpikir kreatif dan mandiri.

Pembelajaran matematika diharapkan menjadi suatu aktivitas yang menyenangkan bagi siswa. Kemampuan matematis salah satunya adalah kemampuan berpikir kreatif yang ditumbuhkan melalui aktivitas belajar matematika (Suherman, 2003). Berpikir kreatif merupakan suatu kemampuan yang harus dimiliki siswa agar pembelajaran matematika tercapai tujuannya. Kemampuan berpikir kreatif dapat diukur berdasarkan indikator fluency (kelancaran/kefasihan), flexibility (keluwesan), orisinil (keaslian), dan elaboration (elaborasi). Kelancaran yaitu menghasilkan jawaban secara benar. Keluwesan adalah menghasilkan jawaban dengan cara yang bervariasi. Keaslian adalah memberikan jawaban dengan menggunakan bahasa, cara, dan ide yang sistematis yang berbeda dengan yang lainnya. Elaborasi adalah memperluas dan memperinci jawaban 
atau gagasan-gagasan baru (Munandar, 2009).

Kenyataan menunjukkan bahwa kemampuan berpikir kreatif siswa masih tergolong sangat rendah. Hal tersebut dikarena kurang perhatiannya siswa pada saat pelaksanaan pembelajaran matematika. Pada saat kegiatan belajar pembelajaran berlangsung, guru hanya mengutamakan logika dan kemampuan komputasi (hitunghitungan) siswa sehingga tingkat kreatifitas berfikir siswa dianggap bukanlah sesuatu yang penting dalam proses belajar mengajar di dalam kelas (Saefuddin, 2012).

Bingolbali (2011) mengatakan bahwa kurangnya berlatih siswa dalam mengerjakan soal yang berkaitan dengan memecahkan masalah. Pembelajaran hanya berpusat kepada guru sehingga kurang melibatkan siswa dalam menyelesaikan soal yang diberikan oleh guru. Guru tidak menggali kreatifitas siswa dalam menyelesaikan soal, karena soal yang diberikan hanya memiliki jawaban benar yang tunggal. Kemudian guru juga tidak terbiasa mengajarkan permasalahan matematika yang memiliki hasil jawaban yang benar lebih dari satu. Keadaan ini mengakibatkan kurang berminatnya siswa dalam menyelesaikan permasalahan dalam matematika yang membutuhkan banyak strategi.

Keadaan yang terjadi mengakibatkan siswa bergantung kepada guru sehingga menyebabkan sumber belajar siswa hanya berpusat pada guru. Keadaan ini mengakibatkan siswa tidak memiliki kemandirian dalam belajar. Kondisi tersebut mengakibatkan siswa tidak memiliki rasa percaya diri dan kemandirian dalam belajar.

Rendahnya kemampuan berpikir kreatif dan kemandirian belajar siswa dalam pembelajaran matematika maka perlu dilakukan suatu upaya untuk meningkatkan kemampuan berpikir kreatif dan kemandirian belajar siswa. Upaya tersebut adalah dengan menerapkan pembelajaran matematika yang memberikan keleluasaan kepada siswa untuk mengembangkan kemampuannya mengemukakan ide dan strategi dalam menyelesaikan masalah.

Pembelajaran yang menekankan keterlibatan siswa menggali ide dan strategi siswa dalam menyelesaikan permasalahan matematika diantaranya dengan menggunakan model Problem Based Learning (PBL). Pembelajaran dengan menggunakan model PBL diawali dengan memberikan masalah kepada siswa. Masalah yang diberikan berasal dari kehidupan nyata atau dalam kehidupan sehari-hari. Permasalahan yang diberikan tidak bersifat tertutup sehingga memungkinkan siswa menggali dan menemukan banyak strategi.

Nasution mengungkapkan bahwa model PBL merupakan suatu pembelajaran yang diawali dengan memberikan masalah nyata kepada siswa. Masalah tersebut kemudian diselidiki dan dicari solusi penyelesaiannya. Masalah yang 
diberikan adalah masalah non-rutin yaitu penyelesaian masalah dengan mengaitkan dunia nyata/ kehidupan sehari-hari, dan penyelesaiannya menggunakan banyak cara atau banyak jawaban (bersifat terbuka) yang memerlukan cara berpikir. Huang (2012) mengungkapkan PBL dapat membantu siswa dalam meningkatkan motivasi intrinsik, kemampuan berpikir, dan mengembangkan pengetahuan tingkat tinggi, serta menjadikan siswa yang mandiri yang dapat bekerja sama dan berkolaborasi dalam kelompoknya.

Pembelajaran model PBL

terdiri dari lima tahap yaitu (1) mengorganisasikan siswa kepada masalah yakni guru menginformasikan tujuan pembelajaran dan memotivasi siswa agar terlibat dalam kegiatan pemecahan suatu masalah, (2) mengorganisasikan siswa untuk belajar yakni guru membantu siswa menentukan dan mengatur tugas-tugas belajar yang berkaitan dengan permasalahan yang diberikan, (3) membantu penyelidikan mandiri dan kelompok yakni guru mendorong siswa mengumpulkan informasi yang sesuai, mencari penjelasan, dan menemukan solusi,

mengembangkan serta mempresentasikan hasil karya yakni guru membantu siswa dalam merencanakan dan menyiapkan hasil karya seperti laporan (5) menganalisis dan melakukan evaluasi proses penyelesaian masalah yakni guru membantu siswa melakukan refleksi atas penyelidikan dan proses yang di gunakan serta membuat kesimpulan.
Kelima tahapan proses pembelajaran model PBL dapat menumbuhkan kemampuan berpikir kreatif dan kemandirian belajar siswa (Rusmono, 2012).

Pembelajaran model PBL telah diterapkan untuk mengembangkan kemampuan berpikir kreatif dan kemandirian belajar. Penelitian yang dilakukan untuk menunjukkan bahwa kemampuan berpikir kreatif dan kemandirian belajar dapat dikembangkan melalui pembelajaran PBL. Hal ini sesuai dengan penelitian Noer (2011), Choridah (2013), Khoiri (2013), \& Nasution (2015) yang mengatakan bahwa pembelajaran dengan menggunakan model PBL dapat mengembangkan kemampuan berpikir kreatif. Hasil penelitian Budiyanto \& Rohaeti (2014) yang menunjukkan bahwa kemandirian belajar siswa dapat dikembangkan melalui pembelajaran PBL.

Penelitian Choridah (2013) menunjukkan bahwa model PBL dapat mengembangkan kemampuan berpikir kreatif siswa, hal tersebut dapat terlihat pada saat siswa menyelesaikan lembar aktivitas siswa dan pada kegiatan pembelajaran yang melibatkan kelompok sehingga mengakibatkan siswa berpacu dalam berkomunikasi terhadap teman dan guru. Penelitian tersebut hanya diberikan tes di awal dan di akhir pembelajaran, tidak diberikan tes uraian harian. Pada penelitian ini, pada saat tahapan pembelajaran membantu penyelidikan mandiri dan kelompok, kemampuan berpikir kreatif dilihat dari dua aspek yaitu secara individu 
dan kelompok. Individu dilihat pada saat siswa menyelesaikan tes uraian harian, sedangkan pada kelompok dilihat pada saat siswa menyelesaikan lembar aktivitas siswa dan pada saat berkomunikasi dengan teman dan guru.

Hasil penelitian Budiyanto \& Rohaeti (2014), mengatakan bahwa pembelajaran model PBL dapat mengembangkan kemandirian belajar siswa,hal itu dapat di lihat pada saat siswa memberi respon terhadap skala kemandirian belajar. Skala kemandirian belajar terdiri dari kategori respon SS (Sangat Sering), $\mathrm{Sr}$ (Sering), Jr (Jarang), dan SJr (Sangat Jarang). Pada penelitian ini, dilihat pada saat siswa memberi respon positif terhadap angket kemandirian belajar yaitu siswa yang memilih respon SS (Sangat Setuju) dan S (Setuju). Angket kemandirian belajar terdiri dari kategori respon SS (Sangat Setuju), S (Setuju), KS (Kurang Setuju), TS (Tidak Setuju), dan STS (Sangat Tidak Setuju).

Berdasarkan uraian yang telah diungkapkan, maka fokus masalah yang ingin peneliti pecahkan dalam penelitian ini adalah bagaimana kemampuan berpikir kreatif siswa selama proses pembelajaran model PBL, apakah terdapat peningkatan kemampuan berpikir kreatif siswa setelah memperoleh pembelajaran model PBL dan bagaimana kemandirian belajar siswa selama proses pembelajaran model PBL.

\section{METODE PENELITIAN}

Metode penelitian ini menggunakan metode campuran (mixed methods). Creswell (2010) menyatakan bahwa pendekatan penelitian metode campuran (mixed methods merupakan penelitian yang mengkombinasikan penelitian kualitatif dan kuantitatif. Penelitian ini menggunakan metode campuran konkuren/satu waktu (concurrent mixed methods) yaitu strategi penelitian yang mengkombinasikan antara metode kualitatif dan metode kuantitatif dalam satu waktu. Bagan strategi embedded konkuren disajikan pada Gambar 1.

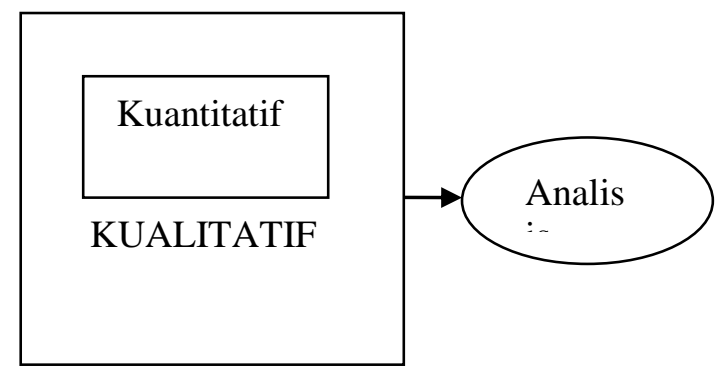

Gambar 1. Bagan strategi embedded konkuren (Creswell, 2010)

Populasi pada penelitian ini adalah seluruh siswa kelas VIII SMP Negeri 16 Banda Aceh yang terdiri dari empat kelas dengan kemampuan akademik setara. Sampel dalam penelitian ini ditentukan dengan teknik random sampling yaitu cara pengambilan sampel secara acak sehingga diperoleh siswa kelas VIII-3 yang diberikan pembelajaran model PBL.

Data pada penelitian ini diperoleh dari seperangkat instrumen yang digunakan yaitu lembar observasi kemampuan berpikir kreatif, 
tes kemampuan berpikir kreatif siswa dalam bentuk soal uraian, dan angket kemandirian belajar. Lembar observasi yang digunakan memuat indikator kemampuan berpikir kreatif meliputi kelancaran, keluwesan, keaslian, dan elaborasi. Tes tertulis terdiri dari satu soal tes uraian harian untuk setiap pertemuan, tiga soal tes awal, dan tiga soal tes akhir. Rubrik kemampuan berpikir kreatif yang diadaptasi dari rubrik berpikir kreatif menurut Hancock (1995).

Angket disusun berdasarkan indikator kemandirian belajar meliputi memiliki inisiatif dan motivasi belajar matematika secara intrinsik, menganalisis tugas dan kebutuhan belajar matematika, menetapkan target belajar matematika, memandang kesulitan belajar matematika sebagai tantangan, dan memiliki rasa percaya diri. Setiap indikator kemandirian belajar divariasikan dengan item-item yang berupa pernyataan tentang kegiatan belajar matematika.

$$
\text { Instrumen tes kemampuan }
$$
berpikir kreatif dan angket kemandirian belajar divalidasi oleh satu orang dosen prodi pendidikan matematika FKIP Universitas Syiah Kuala, satu orang dosen prodi pendidikan matematika FITK UIN ArRaniry, dan satu orang guru matematika SMP Negeri 16 Banda Aceh. Validasi ini dilakukan untuk melihat ketepatan atau kesahihan soalsoal tes dengan indikator kemampuan berpikir kreatif dan item-item pernyataan dengan indikator kemandirian belajar. Berdasarkan penilaian validitas ini, maka dilakukan perbaikan sehingga menghasilkan instrumen tes yang sesuai dan siap digunakan dalam penelitian untuk mengukur kemampuan berpikir kreatif dan kemandirian belajar siswa.

Penelitian ini menggunakan dua jenis data, yaitu data kuantitatif dan data kualitatif. Data kuantitatif berupa data hasil tes kemampuan berpikir kreatif siswa secara individu, sedangkan data kualitatif berupa data hasil observasi kemampuan berpikir kreatif siswa secara kelompok yang dianalisis menggunakan rubrik penilaian kemampuan berpikir kreatif dengan metode deskriptif kualitatif. Data kuantitatif berupa data hasil pretes dan postes yang dianalisis dengan menggunakan uji normalitas, yang kemudian dilanjutkan dengan uji paired- sample $t$ test (uji $\mathrm{t}$ berpasangan), sedangkan data kualitatif berupa angket kemandirian belajar siswa dianalisis dengan menggunakan skala likert dan rumus persentase.

\section{HASIL PENELITIAN}

Kemampuan berpikir kreatif siswa selama proses pembelajaran model PBL dilihat dari dua aspek yaitu individu dan kelompok. Kemampuan berpikir kreatif siswa secara individu.

Peningkatan kemampuan berpikir kreatif siswa setelah memperoleh pembelajaran model PBL, berdasarkan data hasil tes sebelum dan setelah pembelajaran model PBL dilakukan, dianalisa dengan cara membandingkan skor pretes dan postes. Hasil analisis 
statistik deskriptif skor pretes, postes, dan gain dengan bantuan software SPSS versi 22 for Windows pada Tabel 1.

Tabel 1. Statistik deskriptif skor pretes, postes, dan gain kemampuan berpikir kreatif

\begin{tabular}{lcccccc}
\hline & N & \multicolumn{2}{c}{ Min Max } & Mean & Std. Dev & Var \\
\hline Postes & 28 & 27 & 40 & 31.68 & 3.116 & 9.708 \\
\hline Pretes & 28 & 22 & 35 & 27.79 & 3.563 & 12.693 \\
\hline Postes & & & & & & \\
$\begin{array}{l}\text { Pretes } \\
\text { (gain) }\end{array}$ & 28 & 1 & 7 & 3.89 & 1.641 & 2.692 \\
\hline
\end{tabular}

Berdasarkan Tabel 1 diperoleh rata-rata skor pretes, skor postes, dan skor gain (selisih postes-pretes) adalah 27,79; 31,68; dan 3,89. Deskripsi data skor pretes dan skor postes menunjukkan adanya perbedaan ratarata, sedangkan data gain menunjukkan besarnya peningkatan kemampuan berpikir kreatif. Peningkatan kemampuan berpikir kreatif siswa diperlukan uji statistik lanjut.

Uji normalitas pada data skor pretes, postes dan gain dilakukan dengan perhitungan melalui uji Shapiro-Wilk. Kriteria pengujian berdistribusi normal apabila nilai sig.> taraf signifikansi $(\alpha=0,05)$.

Tabel 2. Uji normalitas skor pretes, postes, dan gain kemampuan berpikir kreatif

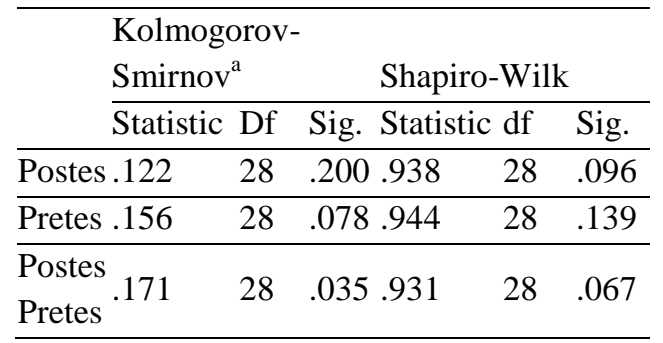

Berdasarkan Tabel 2 diperoleh hasil pretes dan postes kemampuan berpikir kreatif secara keseluruhan menunjukkan nilai Sig. > 0,05, sehingga skor pretes dan postes kemampuan berpikir kreatif berdistribusi normal. Kenormalan skor pretes dan postes dapat dilihat berdasarkan histogram yang terdapat pada Gambar dibawah ini.
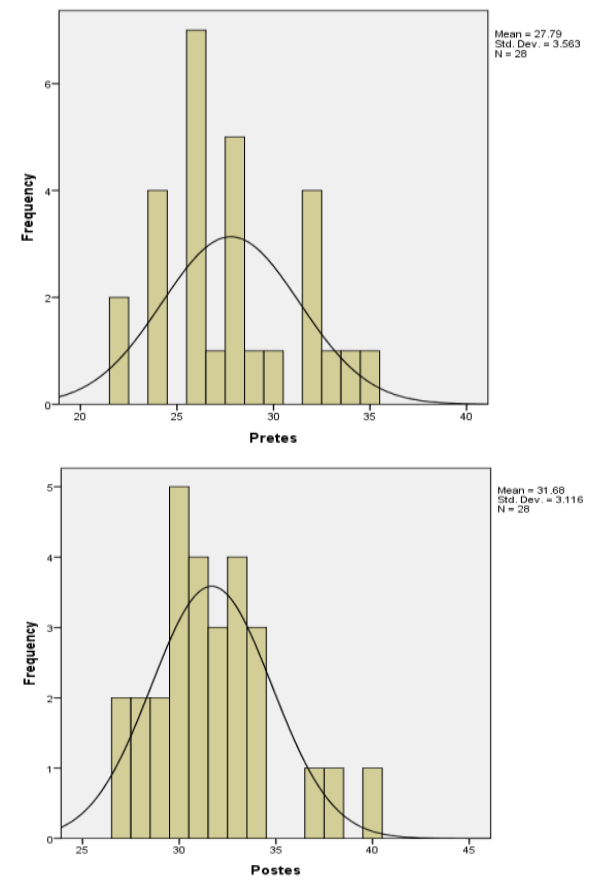

(a)

Gambar 2. (a) Histogram Pretes dan (b) Histogram Postes

Hipotesis dalam penelitian ini adalah terdapatpeningkatan kemampuan berpikir kreatif siswa setelah memperoleh pembelajaran model PBL. Uji hipotesis dilakukan dengan uji statistik paired-samplest test. Kriteria pengujian tolak $\mathrm{H}_{0}$ apabila $t_{\text {hitung }}>\mathrm{t}_{\text {tabel }}$ dan tolak $\mathrm{H}_{0}$ apabila nilai Sig. $<$ taraf signifikansi $(\alpha=0,05)$.

Berdasarkan Tabel 3 berikut ini diperoleh nilai signifikansi sebesar 0,000 nilai tersebut kurang dari nilai $\alpha$ $=0,05$. Nilai t hitung adalah 12,555 
dan $\mathrm{t}$ tabel 2,052, karena nilai Sig. $<\alpha$ dan $\mathrm{t}_{\text {hitung }}>\mathrm{t}_{\text {tabel }}$, maka $\mathrm{H}_{0}$ ditolak dan $\mathrm{H}_{1}$ diterima, sehingga dapat disimpulkan bahwa terdapat peningkatan kemampuan berpikir kreatif siswa selama pembelajaran model PBL.

Tabel 3. Uji t-berpasangan kemampuan berpikir kreatif

Paired Differences

$95 \%$

Confidence

Std. Interval of the

Std. Error Difference

Mean Dev Mean Lower Upper t if tailed) \begin{tabular}{lllllll}
\hline 3.893 & .641 & .310 & 3.257 & 4.52912 .555 & 27 & .000 \\
\hline
\end{tabular}

Pembelajaran model PBL dilakukan sebanyak tiga pertemuan. Berdasarkan data hasil tes uraian harian, maka dipaparkan kemampuan berpikir kreatif secara individu berdasarkan indikator Kelancaran (fluency) pada hasil pertemuan I, II, dan III, siswa paling banyak memperoleh level 4. Pertemuan I, ada $25(89.29 \%)$ siswa memperoleh level 4. Pertemuan II, ada $24(85.71 \%)$ siswa memperoleh level 4. Pertemuan III, ada $16 \quad(57.14 \%)$ siswa memperoleh level 4.

Pada indikator Keluwesan (flexibility) Berdasarkan hasil pertemuan I, II, dan III, siswa paling banyak memperoleh level 4. Pertemuan I, ada $17(60.71 \%)$ siswa memperoleh level 4. Pertemuan II, ada $24(85.71 \%)$ siswa memperoleh level 4. Pertemuan III, ada 16 (57.14\%) siswa memperoleh level 4. Pada indikator Keaslian (originality), Berdasarkan hasil pertemuan I, II, dan
III, siswa paling banyak memperoleh level 0. Pertemuan I, ada $26(92,86 \%)$ siswa memperoleh level 0. Pertemuan II, ada $24(85.71 \%)$ siswa memperoleh level 0.

Pertemuan III, ada 26 $(92,86 \%)$ siswa memperoleh level 0. Pada indikator Elaborasi (elaboration), Berdasarkan hasil pertemuan I, II, dan III, siswa paling banyak memperoleh level 4. Pertemuan I, ada $22(75,57 \%)$ siswa memperoleh level 4. Pertemuan II, ada $24(85.71 \%)$ siswa memperoleh level 4. Pertemuan III, ada $16(57.14 \%)$ siswa memperoleh level 4.

Berdasarkan hasil tes uraian individu dari ketiga pertemuan, maka dapat disimpulkan bahwa indikator kelancaran berada pada level 4 yaitu siswa memberikan satu ide/jawaban yang relevan dan penyelesaiannya benar. Indikator keluwesan berada pada level 4 yaitu siswa memberikan jawaban lebih dari satu cara/beragam, proses perhitungan dan hasilnya benar. Indikator keaslian berada pada level 0 yaitu siswa menjawab tetapi tidak dengan caranya sendiri yang berbeda. Indikator elaborasi berada pada level 4 yaitu siswa memberi jawaban yang benar dan rinci dengan memberikan kesimpulan.

Bila ditinjau dari Kemampuan berpikir kreatif siswa secara kelompokmaka pada Pertemuan I, Berdasarkan hasil kerja kelompok siswa pada pertemuan I, indikator kelancaran dari kelompok 1 sampai dengan kelompok 6 memperoleh level 4 yaitu siswa memberikan satu 
ide/jawaban yang relevan dan penyelesaiannya benar.

Indikator keluwesan dari kelompok 1 sampai dengan kelompok 6 memperoleh level 4 yaitu siswa memberikan jawaban lebih dari satu cara/beragam, proses perhitungan dan hasilnya benar. Indikator keaslian, kelompok 2, 3, 5, dan 6 memperoleh level 4 yaitu siswa memberi jawaban dengan caranya sendiri yang berbeda, proses perhitungan dan hasilnya benar, sedangkan kelompok 1 dan 4 memperoleh level 0 yaitu siswa menjawab tetapi tidak dengan caranya sendiri yang berbeda, proses perhitungan dan hasilnya benar. Indikator elaborasi dari kelompok 1 sampai kelompok 6 memperoleh level 4 yaitu siswa memberi jawaban yang benar dan rinci serta memberikan kesimpulan.

Pada pertemuan II Berdasarkan hasil kerja kelompok siswa pada pertemuan II, indikator kelancaran kelompok 2,3, 4, dan 6 memperoleh level 4 yaitu siswa memberikan satu ide/jawaban yang relevan dan penyelesaiannya benar, selanjutnya kelompok 1 dan 5 memperoleh level 3 yaitu siswa memberikan satu atau lebih ide/jawaban yang relevan tetapi proses perhitungan belum selesai.

Indikator keluwesan hanya kelompok 4 yang memperoleh level 4 yaitu siswa memberikan jawaban lebih dari satu cara/beragam, proses perhitungan dan hasilnya benar, kelompok 1 dan 5 memperoleh level 3 yaitu siswa memberikan jawaban lebih dari satu cara/beragam tetapi proses perhitungan belum selesai, selanjutnya kelompok 2, 3, dan 6 memperoleh level 2 yaitu siswa memberikan jawaban dengan satu cara, proses perhitungan dan hasilnya benar. Indikator keaslian kelompok 1 dan 5 memperoleh level 1 yaitu siswa memberi jawaban dengan caranya sendiri yang berbeda tetapi kurang/tidak dapat dipahami, sedangkan kelompok 2, 3, 4, dan 6 memperoleh level 0 yaitu siswa tidak menjawab tetapi tidak dengan caranya sendiri yang berbeda.

Indikator elaborasi kelompok 2, 3, 4, dan 6 memperoleh level 4 yaitu siswa member jawaban yang benar dan rinci, selanjutnya kelompok 1 dan 5 memperoleh level 3 yaitu proses perhitungan tidak selesai tetapi memberikan kesimpulan.

$$
\text { Pada pertemuan III, }
$$

Berdasarkan hasil kerja kelompok siswa pada ketiga pertemuan, indikator kelancaran kelompok 1, 3, 4, dan 6 memperoleh level 4 yaitu siswa memberikan satu ide/jawaban yang relevan dan penyelesaiannya benar, selanjutnya kelompok 2 dan 5 memperoleh level 3 yaitu siswa memberikan satu atau lebih ide/jawaban yang relevan tetapi proses perhitungan belum selesai.

Indikator keluwesan kelompok 3 dan 5 memperoleh level 4 yaitu siswa memberikan jawaban lebih dari satu cara/beragam, proses perhitungan dan hasilnya benar, kelompok 2 memperoleh level 3 yaitu siswa memberikan jawaban lebih dari satu cara/beragam tetapi proses perhitungan belum selesai, selanjutnya kelompok 1, 4, dan 6 memperoleh level 2 yaitu siswa memberikan jawaban 
dengan satu cara, proses perhitungan dan hasilnya benar.

Indikator keaslian kelompok 2 dan 5 memperoleh level 1 yaitu siswa memberi jawaban dengan caranya sendiri yang berbeda, proses perhitungan sudah terarah tetapi tidak selesai (kurang dipahami), sedangkan kelompok 1, 3, 4, dan 6 memperoleh level 0 yaitu siswa menjawab tetapi tidak dengan caranya sendiri yang berbeda. Indikator elaborasi kelompok 1, 2, 3, 4 dan 6 memperoleh level 4 yaitu siswa memberijawaban yang benar dan rinci dengan memberikan kesimpulan, selanjutnya kelompok 5 memperoleh level 3 yaitu proses perhitungan tidak selesai tetapi memberikan kesimpulan.

\section{PEMBAHASAN}

Berdasarkan uraian di atas dapat disimpulkan bahwa siswa kreatif dalam menyelesaikan masalah yang berkaitan dengan perbandingan baik secara individu maupun kelompok selama proses pembelajaran model PBL. Selama propses pembelajaran, saat bekerja secara individu, siswa lancar dalam menjawab tetapi masih ada siswa yang tidak menyertakan beragam cara dalam menyelesaikan masalah dan hanya sedikit siswa yang menyelesaikan masalah dengan caranya sendiri yang berbeda dengan teman sekelasnya, serta ada siswa yang tidak mendetailkan jawaban atau tidak memberikan kesimpulan dari hasil yang didapat. Pada saat bekerja secara kelompok, siswa bekerja sama berusaha menyelesaikan masalah dengan kreatif sehingga mendapatkan jawaban yang bervariasi, meskipun masih ada jawaban yang sama antara satu kelompok dengan kelompok lainnya. Ada pula kelompok yang lancar menjawab dan memberi jawaban detail dengan kesimpulan namun masih ada kelompok yang tidak menyertakan beragam cara dalam menyelesaikan masalah dan hanya sedikit kelompok yang menyelesaikan masalah dengan caranya sendiri yang berbeda dengan kelompok lainnya.

Rata-rata skor pretes, postes, dan gain yaitu 27,79; 31,68; dan 3,89. Data gain yang diperoleh dari selisih antara postes dan pretes menunjukkan adanya peningkatan kemampuan berpikir kreatif. Hal ini juga terlihat dari hasil uji t berpasangan dari pretes dan postes yang memperoleh nilai signifikansi 0,000 kurang dari nilai $\alpha$ $=0,05$ dan nilai $\mathrm{t}$ hitung 12,555 lebih dari nilai t-tabel sesuai dengan kriteria uji t berpasangan, dalam hal ini tolak $\mathrm{H}_{0}$ dan terima $\mathrm{H}_{1}$, sehingga dapat disimpulkan bahwa terjadi peningkatan kemampuan berpikir kreatif siswa setelah pembelajaran model PBL diberikan. Dengan demikian pembelajaran dengan model PBL dapat meningkatkan kemampuan berpikir kreatif siswa.

Kemandirian belajar siswa selama proses pembelajaran model PBL dilihat dari hasil angket. Angket kemandirian belajar siswa memuat 15 item pernyataan yang disusun berdasarkan lima indikator kemandirian belajar. Angket menggunakan Skala Likert yang terdiri dari kategori respon SS (Sangat 
Setuju), S (Setuju), KS (Kurang Setuju), TS (Tidak Setuju), dan STS (Sangat Tidak Setuju).

Berdasarkan hasil data angket, $80,24 \%$ menunjukkan respon yang positif (SS dan S) terhadap 15 item pernyataan. Hal ini berarti siswa memiliki kemandirian belajar selama proses pembelajaran dengan model PBL.

Berdasarkan pembahasan hasil penelitian yang telah diuraikan, maka terlihat pembelajaran dengan model PBL dapat meningkatkan kemampuan berpikir kreatif dan kemandirian belajar siswa. Hal ini sesuai dengan hasil penelitian Budiyanto dan Rohaeti (2014) yang menunjukkan bahwa pembelajaran model PBL dapat meningkatkan kemampuan berpikir kreatif dan kemandirian belajar siswa.

\section{SIMPULAN}

Berdasarkan hasil penelitian dan pembahasan, maka dapat disimpulankan terdapat peningkatan kemampuan berpikir kreatif siswa setelah memperoleh pembelajaran model PBL. Pada penelitian ini juga diperoleh hasil Siswa memiliki kemandirian belajar selama proses pembelajaran model PBL.

\section{DAFTAR PUSTAKA}

Bingolbali, E. (2011). Multiple Solution to Problems in Mathematics Teaching: Do Teachers Really Value Them?. Australian Journal of Teacher Education, 36(1); 18-31.

Budiyanto, A. M. \& Rohaeti, E. E. (2014). Mengembangkan Kemampuan Berpikir Kreatif dan Kemandirian Belajar Siswa SMA melalui Pembelajaran Berbasis Masalah. Jurnal Program Pascasarjana STKIP Siliwangi Bandung, 19(2); 166172.

Choridah, D. T. (2013). Peran Pembelajaran Berbasis Masalah untuk Meningkatkan Kemampuan Komunikasi dan Berpikir Kreatif serta Disposisi Matematis Siswa SMA. Jurnal Ilmiah Program Studi Matematika STKIP Siliwangi Bandung, 2(2); 194-202.

Creswell, J. W. (2010). Research Design: Pendekatan Kualitatif, Kuantitatif, dan Mixed. (Terjemahan Achmad Fawaid). Yogyakarta: Pustaka Pelajar. (Buku asli diterbitkan tahun 2009).

Hancock, C. L. (1995). Enhancing Mathematics Learning with Open-Ended Questions. The Mathematics Teacher, 88(6); 496-499.

Huang, Kuo-shu and Tzu-Pu Wang. (2012). Applying Problem Based Learning (PBL) in University. The Journal of International Management Studies, 7(1); 121-127.

Khoiri, W. (2013). Problem Based Learning berbantuan Multimedia dalam Pembelajaran Matematika untuk Meningkatkan Kemampuan Berpikir Kreatif. Jurnal Pendidikan Matematika UNNES, 2(1); 114-121.

Mulyono, A. (2003).Pendidikan bagi Anak Berkesulitan Belajar. Jakarta: Rineka Cipta.

Munandar, U. (2009). Pengembangan Kreativitas Anak Berbakat. Jakarta: Rineka Cipta.

Nasution, P. R. (2015). Perbedaan Peningkatan Kemampuan 
Berpikir Kreatif Matematis dan Kemandirian Belajar Siswa pada Pembelajaran Berbasis Masalah dan Pembelajaran Konvensional di SMPN 4 Padangsidempuan. Jurnal Paradikma, 8(3); 38-50.

Noer, S. H. (2011). Kemampuan Berpikir Kreatif Matematis dan Pembelajaran Matematika Berbasis Masalah open-ended. Jurnal Pendidikan Matematika, 5(1); 104-111.

Rusmono. (2012). Strategi Pembelajaran dengan Problem Based Learning itu perlu. Bogor: Ghalia Indonesia

Saefuddin, A. A. (2012). Pengembangan Kemampuan Berpikir Kreatif dalam Pembelajaran Matematika dengan Pendekatan Pendidikan Matematika Realistik Indonasia (PMRI). Jurnal Universitas PGRI Yogyakarta, 4(1); 37-48.

Suherman, E. (2003). Strategi Pembelajaran Matematika Kontemporer. Bandung: Jurusan Pendidikan Matematika FPMIPA UPI. 